\title{
Studi Awal Pengaruh Variasi Kuat Arus terhadap Kekuatan Tarik Hasil Pengelasan SMAW Material Karbon JIS G3106 dengan Filler E6013
}

\author{
Ely Aprilia ${ }^{1 *}$, Amelia Rahmatika ${ }^{1}$, Megarini Hersaputri ${ }^{1}$ dan Setiani Ibrahim ${ }^{1}$ \\ ${ }^{1}$ Program Studi Teknologi Pengelasan dan Fabrikasi, Fakultas Vokasi, Institut Teknologi Sains Bandung \\ *Email korespondensi: aprilia.ely@gmail.com
}

\begin{abstract}
Abstrak. Kekuatan tarik hasil pengelasan merupakan salah satu sifat mekanik yang menyatakan kualitas hasil pengelasan. Pemilihan heat input dalam proses pengelasan menjadi sangat penting karena berpengaruh pada kualitas hasil pengelasan.Salah satu parameter penting dalam menentukan heat input adalah tegangan, kecepatan pengelasan dan arus yang digunakan pada proses pengelasan. Pada penelitian ini tegangan dan kecepatan pengelasan dibuat tetap sedangkan arus dibuat bervariasi. Salah satu pengeruh arus pada pengelasan akan menentukan tembusan hasil pengelasan. Dengan tembusan yang baik diharapkan kekuatan tarik akan meningkat. Peningkatan kuat tarik menjadi salah satu parameter kualitas hasil pengelasan. Tujuan dari penelitian ini adalah untuk mengetahui pengaruh variasi arus pengelasan pada kekuatan hasil tarik pengelasan material JIS G 3016 SM400A. Material JIS G3106 dipilih kerena material ini adalah material yang sering digunakan di bidang konstruksi. Proses pengelasan yang dilakukan dalam penelitian ini adalah proses pengelasan Shield Metal Arc Welding (SMAW) menggunakan filler E 6013 dengan diameter 2,6 mm dengan variasi arus DC polaritas EN sebesar $80 \mathrm{~A}$, 90 A dan 100 A. Spesimen disiapkan dengan kampuh las berberbentuk single V. Pengujian yang dilakukan dalam penelitian ini adalah uji tarik menggunakan standar ASME Sec.IX: 2013 untuk mengetahui pengaruh variasi arus yang digunakan terhadap kekuatan tarik. Data yang dihasilkan pada pengujian tarik berupa data Tensile strength selain itu dilakukan pula uji Makroskopik menggunakan standar ASTM E340-13 untuk mengetahui kualitas hasil las. Hasil pengujian menunjukan bahwa kekuatan tarik terbesar dihasilkan oleh pengelasan dengan arus 100A sebesar 584,2 MPa.
\end{abstract}

Kata kunci: Karbon JIS G3106 SM400A, pengelasan SMAW, arus pengelasan, kuat tarik 


\section{Pendahuluan}

Bidang konstruksi dan manufaktur di Indonesia berkembang dengan pesat sejalan dengan kebutuhan masyarakat dalam hal insfrakstruktur. Bidang ini erat kaitannnya dengan bidang pengelasan terutama dalam hal penyambungan logam. Dalam definisi DIN ( Deutsche Industrie Norman ) pengelasan artinya ikatan metalurgi pada sambungan logam atau logam paduan yang dilaksanakan dalam keadaan lumer atau cairan.

Metoda pengelasan manual yang sering digunakan adalah metoda SMAW (Shielded Metal Arc Welding). Metoda ini merupakan metoda yang mamiliki keunggulan diantaranya adalah tahan terhadap terpaan angin sehingga pengelasan SMAW dapat dilakukan dimana saja termasuk di luar ruangan (field use), ringkas karena tidak memerlukann gas dan dapat dilakukan pada semua posisi pengelasan. Oleh karena itulah pengelasan SMAW dipilih sebagai metoda pengelasan yang dipakai dalam penelitian ini. Material JIS G 3016 juga merupakan material yang sering digunakan di bidang konstruksi.

Pada penelitian ini dilakukan pengujian tarik terhadap hasil pengelasan SMAW posisi flat $1 \mathrm{G}$ pada material JIS G3106. Pengelasan menggunakan filler metal E6013 berdiameter 2,6 mm dengan variasi arus DCEN 80 A, 90 A dan 100 A untuk mengetahui pengaruh arus pada kekuatan tarik material hasil pengelasan SMAW.

\section{Teori}

Kekuatan hasil proses pengelasan ditentukan oleh banyak faktor diantaranya adalah jenis material filler yang digunakan yang sesuai dengan material induk, parameter heat input pada proses pengelasan yang tepat dan jenis proses pengelasan yang dilakukan.

\subsection{Baja Karbon G 3106}

G 3106 SM400 merupakan jenis baja karbon yang memiliki kandungan karbon $0,23 \%$. Merupakan baja jenis structural streel plate yang banyak digunakan di bidang konstruksi. Tipe baja ini memiliki sifat kemampulasan yang baik. Namun pada pengelasan dengan kecepatan tinggi berpotensi cacat porositas. Karena sifat kemampulasannya yang baik, baja jenis ini banyak dipakai di bidang konstruksi.
Tabel 1. komposisi kimia G 3106 (JIS G3106 standard) dan E 6013 (Nikko steel datasheet RD-260)

\begin{tabular}{|c|c|c|c|c|c|}
\hline Material & $\begin{array}{c}\mathbf{C} \\
(\boldsymbol{\%})\end{array}$ & $\begin{array}{c}\mathbf{S i} \\
(\mathbf{\%})\end{array}$ & $\begin{array}{c}\mathbf{M n} \\
(\boldsymbol{\%})\end{array}$ & $\begin{array}{c}\mathbf{P} \\
(\boldsymbol{\%})\end{array}$ & $\begin{array}{c}\mathbf{S} \\
(\mathbf{\%})\end{array}$ \\
\hline G 3106 & Max & - & Max & Max & Max \\
SM400A & 0,23 & $\begin{array}{c}2,5 \\
\mathbf{x} \\
\mathbf{C}^{(1)}\end{array}$ & 0,035 & 0,035 \\
\hline $\begin{array}{c}\text { Filler E } \\
\text { 6013 } \\
\text { (Tipikal } \\
\text { weldmetal) }\end{array}$ & 0,08 & 0,3 & 0,5 & 0,02 & 0,02 \\
\hline
\end{tabular}

Pengelasan SMAW untuk baja karbon jenis ini menggunakan logam pengisi E6013 dengan tipikal kakuatan tarik sebesar $520 \mathrm{MPa}$ (Nikko Steel Datasheet RD-260)

\subsection{Pengelasan SMAW}

Proses pengelasan Shielded Metal Arc Welding (SMAW) merupakan proses pengelasan dengan busur listrik, dimana panas didapatkan dari busur menyala yang memancar di antara elektoda fluks dan material induk. SMAW merupakan proses pengelasan manual. Kualitas pengelasan selain ditentukan oleh parameter fisis, juga ditentukan oleh kemahiran juru las dalam melakukan proses pengelasan. Proses pengelasan ini tahan terhadap tiupan angin, sehingga sampai saat ini masih banyak digunakan meskipun banyak teknologi pengelasan lainnya yang sudah otomatis.

Proses pengelasan SMAW membutuhkan elektroda habis dilapisi fluks sebagai logam pengisi. Fluks pada elektroda akan menghasilkan gas pada saat proses pengelasan untuk melindungi logam las dari kecacatan. Karena prosesnya yang manual, juru las harus dapat mengontrol parameter pengelasan seperti panjang busur, sudut elektroda, kecepatan pengelasan dan kuat arus yang digunakan pada saat mengelas.

\subsection{Heat inputdan kuat arus dalam proses pengelasan}

Sumber masukan panas (Heat input) adalah besarnya energi panas tiap satuan panjang las ketika sumber panas bergerak. Heat input dalam proses pengelasan ditentukan oleh beberapa parameter diantaranya adalah kuat arus. 
$H I=\eta \frac{\text { tegangan las }(V) \times \text { kuat arus las }(A)}{\text { kecepatan pengelasan }(v)}$

Dengan $\eta$ adalah efisiensi panas pengelasan yang bergantung pada jenis proses pengelasan.

Kuat arus berbanding lurus dengan besarnya energi dalam dalam proses pengelasan yang juga menentukan dalamnya penetrasi. Arus yang rendah akan mengekibatkan penetrasi dangkal, namun arus tinggi juga akan mengakibatkan daerah las melebar yang akan mengakibatkan deformasi pada hasil lasan.

Pemilihan kuat arus bergantung pada jenis elektroda yang digunakan, diameter elektroda, jenis dan ketebalan material induk.

\subsection{Metalurgi Pengelasan}

Proses pengelasan melibatkan proses pemanasan dan pendinginan material. Hasilnya terdapat siklus pemanasan pada material hasil las. Siklus pemanasan dibagi menjadi tiga bagian yaitu,

1. Daerah lasan (weld metal), daerah pada logam yang mencair pada saat pengelasan, dan terjadi pencampuran kemudian akan membeku.Daerah khusus yang membatasi antara daerah lasan dan dengan daerah pengaruh panas disebut daerah fusi (fusion line)

2. Daerah pengaruh panas (heat affected zone), daerah pada logam yang mengalami perubahan struktur mikro akibat siklus termal pemanasan dan pendinginan yang cepat.

3. Daerah logam induk (base metal), daerah pada logam yang tidak mengalami perubahan sifat dan struktur mikro akibat temperatur pengelasan

\section{Metode Penelitian}

Material uji yang digunakan dalam penelitian ini adalah baja karbon JIS G3106 SM400A. Ukuran material uji dapat dilihat pada tabel 2.

Tebel 2. ukuran material uji

\begin{tabular}{|l|l|l|}
\hline No Spesimen & $\begin{array}{c}\text { Lebar x tebal } \\
(\mathbf{m m})\end{array}$ & $\begin{array}{c}\text { Luas } \\
\text { penampang } \\
\left(\mathbf{m m}^{\mathbf{2}}\right)\end{array}$ \\
\hline $1(80 \mathrm{~A})$ & $19,28 \times 5,23$ & 100,83 \\
\hline $2(90 \mathrm{~A})$ & $18,99 \times 5,19$ & 98,56 \\
\hline $3(100 \mathrm{~A})$ & $18,82 \times 4,73$ & 89,02 \\
\hline
\end{tabular}

Proses pengelasan posisi flat 1G SMAW bentuk kampuh single $\mathrm{V}$ dengan logam pengisi E6013 berdiameter 2,6mm. Pemilihan jenis logam pengisi berdasarkan kekuatan tarik material JIS
G 3106 sebelum dilakukan pengelasan. Kuat tarik logam JIS G 3106 SM400A sebesar 400$510 \mathrm{MPa}$. Komposisi logam pengisi dapat dilihat pada tabel 1.

Pengelasan SMAW pada material uji menggunakan variasi arus DCEN 80A, 90A dan 100A. Setelah itu material disiapkan berdasarkan standar ASME sect IX:2013 untuk dilakukan pengujian kekuatan tarik. Sebagai data pendukung untuk mengidentifikasi kualitas proses pengelasan, dilakukan juga uji makroskopik dengan standar ASTM E 340-13.

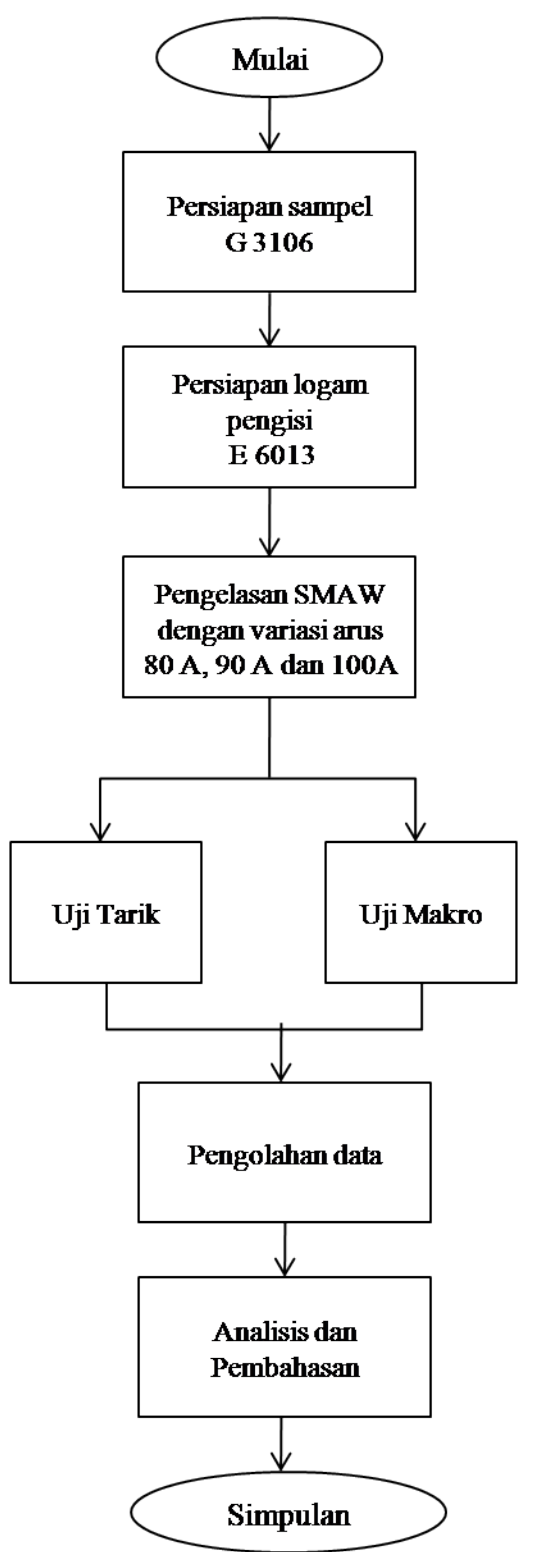

Gambar 1. diagram alir metode penelitian 


\section{Hasil dan Pembahasan}

\subsection{Pengaruh kuat arus terhadap kekuatan tarik sambungan las}

Tabel 3. hasil uji tarik

\begin{tabular}{|c|c|c|c|}
\hline $\begin{array}{c}\text { No } \\
\text { Spesimen }\end{array}$ & $\begin{array}{c}\text { Kuat } \\
\text { Arus } \\
\text { (A) }\end{array}$ & $\begin{array}{c}\text { Beban } \\
\text { Maks } \\
\text { (kgf) }\end{array}$ & $\begin{array}{c}\text { Kuat Tarik } \\
\text { (Tensile } \\
\text { Strength) } \\
\left(\mathbf{k g f} / \mathbf{m m}^{2}\right) \\
(\mathbf{M P a})\end{array}$ \\
\hline 1 & 80 & 4133,85 & $\begin{array}{c}41,00 \\
(402)\end{array}$ \\
\hline 2 & 90 & 4461,00 & 45,26 \\
$(444)$
\end{tabular}

Hasil pengujian tarik menunjukan kekuatan tarik hasil pengelasan SMAW material G 3106 pada variasi arus 80A, 90A dan 100A mengalami perubahan. Untuk kuat arus $80 \mathrm{~A}$ kekuatan tarik yang dihasilkan sebesar $402 \mathrm{MPa}$, sedangkan untuk kuat arus 90A dan $100 \mathrm{~A}$ masing-masing sebesar $444 \mathrm{MPa}$ dan 584,2 MPa dengan kondisi semua sambungan putus pada bagian weld metal. Dari ketiga data tersebut dapat disimpulkan bahwa kenaikan arus pada pengelasan SMAW material G 3106 meningkatkan kakuatan tarik hasil pengelasan. Hal ini disebabkan kuat arus yang tinggi akan menghasilkan tembusan yang baik pada pengelasan. Kondisi tersebut dapat terbukti dari hasil pengamatan kekuatan tarik hasil pengelasan dengan arus 100A lebih tinggi dari tipikal kuat tarik material induk yang menurut standar JIS G3106 sebesar $510 \mathrm{MPa}$.

\subsection{Kualitas hasil pengelasan berdasarkan uji makroskopik}

Tabel 4. hasil pengujian makroskopik

\begin{tabular}{|c|c|}
\hline $\begin{array}{c}\text { No } \\
\text { Spesimen }\end{array}$ & Gambar Makro \\
\hline \multirow{3}{*}{$1(80 \mathrm{~A})$} & \\
& \\
& \|\|\|\|\|\|\|\|\|\|\|\| \\
\hline
\end{tabular}

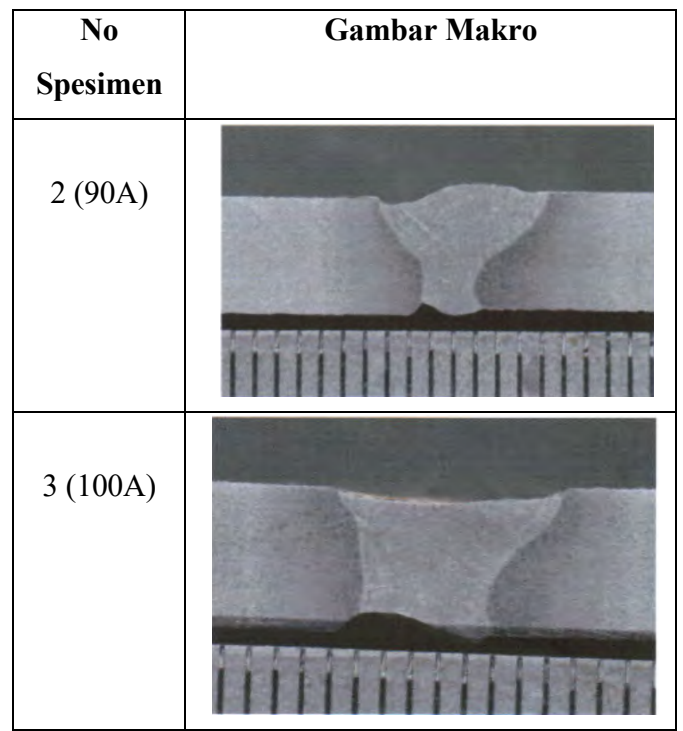

Pengelasan SMAW sangat bergantung pada kemampuan juru las dalam menantukan parameter dan keterampilan proses mengelasnya. Dari hasil uji makro dengan perbesaran kamera 4 kali dan perbesaran makro 10 kali didapatkan hasil seperti tabel 4. Dari ketiga spesimen menujukan tembusan yang kurang baik untuk ketiga spesimen. Cacat pengelasan ini sedikit banyak akan mempengaruhi kekuatan uji tarik. Walaupun demikian dari hasil uji tarik didapatkan bahwa semakin besar arus yang digunakan, kekuatan tarik dari weld metal yang dihasilkan juga semakin besar. Pembuktian lebih dalam pada penelitian lanjutan diperlukan dengan cara menambah jumlah spesimen penelitian dengan rentang variasi arus yang lebih banyak.

\section{Simpulan dan saran}

Penelitian ini manghasilkan kesimpulan dan saran sebagai berikut:

1. Semakin besar arus pada pengelasan SMAW kekuatan tarik juga akan semakin besar. Namun demikian diperlukan tambahan data untuk menghasilkan data arus optimal pengelasan agar kekuatan tarik logam las dapat lebih besar dari kekuatan tarik logam induk.

2. Kekuatan tarik terbesar pada penelitian ini dihasilkan oleh arus 100A dengan kuat tarik sebesar 584,2 $\mathrm{MPa}$ 


\section{Ucapan terima kasih}

Penulis mengucapkan terima kasih kepada LPPM ITSB dalam program penelitian internal ITSB

\section{Referensi}

Shomad, M. A., \&Mushafi, M. S. (2017). Analisis Pengaruh Variasi Elektroda Las E 6013 Dan E 7018 terhadap
Kekuatan Tarik dan Kekerasan Baja SS 400. Dinamika Teknik Mesin, vol 7 no 2 , 74-79. https://doi.org/10.29303/dtm.v7i2.156

Wibowo, H., Ilman, M.N. \& Iswanto, P.T. (2016). Analisa Heat Input Pengelasan terhadap Distorsi, Struktur Mikro dan Kekuatan Mekanis Baja A36. Jurnal Rekayasa Mesin, vol 7 no 1, 5-12. 